\title{
Andragogy in the context of teaching Lean management
}

\author{
Nadezhda Davydova \\ Project Manager, PhD, Rosatom production system, Moscow
}

\begin{abstract}
The article discusses the major issues of teaching lean management for adults and provides the rational to transfer from pedagogy model to andragogy model of teaching. The model of lean personality is designed. The educational principles in lean production are also analyzed. The article submits the forms of the lean education with the focus on Process Enterprise as the most important.
\end{abstract}

Keywords: lean production, andragogy, model of lean personality, process enterprise.

\section{Introduction}

In connection with the implementation of the Effective Region project by the State Atomic Energy Corporation Rosatom, as well as the implementation of the national project "Labor Productivity and Employment Support", the necessary conditions have been created for enhancing the activities of various economic entities in the field of lean management, which has led to an increase in the need for lean staff. Currently, there is a significant shortage of professional personnel in the field of lean management at all levels, from the worker to the owner of the business, and the demand for them is significantly ahead of the supply on the labor market. And this trend will continue if drastic measures are not taken.

Of course, the task of training lean employees is solved by the enterprises themselves with the help of corporate universities. Universities that provide economical knowledge, ranging from continuing education courses to master's programs and MBAs in the field of lean management, join the training of lean personnel. There are also various consulting structures that are actively involved in implementing lean projects and developing a lean manufacturing management system in organizations. Because of the diversity of participants in the education system in the field of lean technologies, the question naturally arises of the quality of the transfer of lean knowledge and the effectiveness of training. The difference in educational approaches is reflected in the significant variability of knowledge among consumers of these services. It should be noted that some uniformity in the field of terminology appeared due to the GOSTs of the Lean Manufacturing series [1].

In order to transfer lean knowledge, representatives of lean universities and JSC Rosatom Production System created an Association of Lean Universities, which brought together 14 organizations. The Association is developing methods, for example, reference advanced training courses "Project Management in Lean Manufacturing", a regulation on evaluating a factory of processes, a model and criteria for a lean university. All these activities are designed to form a certain culture of knowledge transfer in the field of lean technologies in the country, including an emphasis on on-site training. 


\section{Methods and materials}

When creating a culture of knowledge transfer in the field of lean technologies, it is important to consider that teachers need to move from a pedagogical model of knowledge transfer to andragogical [2]. Zmeev S.I. notes that in the andragogical model of learning, the learner himself plays the leading role in organizing the learning process at all its stages. An adult student is an active element, one of the equal subjects of the learning process [3, p.21]. Unfortunately, we often forget about this and keep the pedagogical model of teaching with adults, where the student is completely dependent on the teacher, who determines what and how should be studied. In this case, the teachers put the adult in the position of a child where he does not see the goal in the field of education, does not participate actively and, as a result, is not responsible for learning and does not receive full knowledge. Since the student did not make the learner an active element of the learning system in the pedagogical model, the adult is not in an active position, so he is not further interested in actively applying the knowledge gained.

In addition, the main task of teaching lean technologies is the transformation of a person into a lean person, and for this it is necessary to create essential conditions under which lean knowledge becomes a means of realizing his ambitious life goals. Lean knowledge transforms not only the workspace, but also the person himself - he becomes different, more purposeful, and more conscious.

The main characteristics of a lean person are given in table 1 .

Table 1. Characteristics of a lean person

\begin{tabular}{|c|c|c|}
\hline Characteristics & Point of view & Description \\
\hline $\begin{array}{c}\text { Mission. Personality } \\
\text { strength }\end{array}$ & Worldview & $\begin{array}{c}\text { Awareness in life. Self-awareness. Understanding } \\
\text { and recognition of your mission. Happiness. } \\
\text { Development. Creation. Ethics of work and } \\
\text { service to society. Feeling yourself a citizen of the } \\
\text { world. }\end{array}$ \\
\hline $\begin{array}{c}\text { Commitment to LP } \\
\text { values and } \\
\text { principles }\end{array}$ & Value & $\begin{array}{c}\text { Respect for the person. Focus on creating value } \\
\text { for the client. One team. Efficiency. One step } \\
\text { ahead. Security. }\end{array}$ \\
\hline $\begin{array}{c}\text { Ability to determine } \\
\text { and achieve goals }\end{array}$ & Proactive & $\begin{array}{c}\text { We are sure that we are able to change something } \\
\text { and we feel the importance of our actions. } \\
\text { Ambitious goal. A vision of a long-term goal and } \\
\text { constant kaizen in tactics. Solving problems on } \\
\text { the way to achieving the goal. Focus on quality } \\
\text { and service. Initiative (start with yourself). } \\
\text { Persistence in achieving goals. }\end{array}$ \\
\hline $\begin{array}{c}\text { Design, process and } \\
\text { stream thinking }\end{array}$ & Process & $\begin{array}{c}\text { Understanding of causes and effects. The ability } \\
\text { to see and manage the flow of value creation for } \\
\text { the client. Analytical thinking. Short-term and } \\
\text { effective projects. Striving for completion of } \\
\text { projects. Cross-functionality. }\end{array}$ \\
\hline $\begin{array}{c}\text { Knowledge and } \\
\text { mastery of lean } \\
\text { manufacturing } \\
\text { methods }\end{array}$ & Instrumental & $\begin{array}{c}\text { Value stream mapping. Organization of the } \\
\text { workspace. Standardized work. Kanban. TPM. } \\
\text { SMED et al. }\end{array}$ \\
\hline $\begin{array}{c}\text { Creativity and } \\
\text { innovation }\end{array}$ & Creative & $\begin{array}{c}\text { The flexibility of thinking. Ability to } \\
\text { learn/unlearn/relearn. Possess soft skills. Learning } \\
\text { through activities. Adaptability. The ability to see } \\
\text { the world as an opportunity. }\end{array}$ \\
\hline
\end{tabular}




\begin{tabular}{|c|c|c|}
\hline Human interaction & Communicative & $\begin{array}{c}\text { Teamwork motivation. Emotional intelligence. } \\
\text { Coordinated actions with other people. } \\
\text { Negotiation. }\end{array}$ \\
\hline Efficiency & Activity & $\begin{array}{c}\text { Personal effectiveness. Self-control. Emphasis on } \\
\text { the quality and duration of the process. Ability to } \\
\text { focus on customer values. Holistic education and } \\
\text { development. }\end{array}$ \\
\hline
\end{tabular}

These main characteristics of a lean person, shown in Table 1, can be represented as a model of the competencies of a lean person (Figure 1).

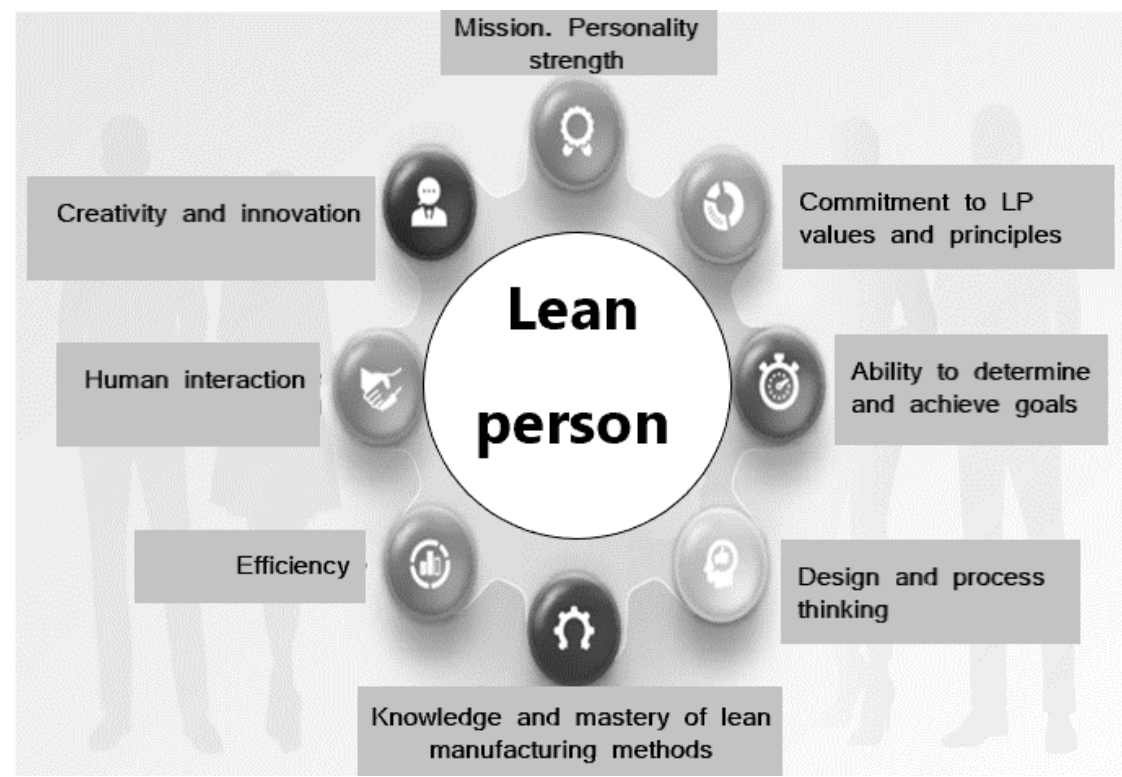

Fig. 1. The model of competencies of a lean person, compiled by the author

In the model of competencies of a lean person, special attention is paid to the worldview and value issues of personality development, specifics of thinking, as well as specific skills in the field of lean manufacturing methods and tools. It is important to note that the use of tools for the sake of the tools themselves only contributes to increase reporting and discredits the very idea of lean management. "Knowledge and skills that are not connected with human values pose a mortal threat to the existence of mankind! But values - moral, aesthetic, existential, and religious - are complementary with knowledge and therefore are able to regulate cognitive, and all others, forms of human activity - this gives reason to use the concept of "value orientations" to explain human behavior" [4, p. 129]. That is why, in the model of competencies of a lean person, special attention is paid to the worldview and value issues of personality development.

In the case of the formation and development of a lean person, it is appropriate to talk about a completely different, new role for the teacher who transfers this living knowledge and teaches its use. The traditional scheme, in which knowledge is transferred from teacher to student, works with extremely low efficiency and effectiveness. Knowledge does not work on its own, it is no longer self-worth. It is important how we apply this knowledge; how effective it is. By transferring lean knowledge in the framework of on-site training, we understand that we transfer not only knowledge, not only form specific skills, but also form a new quality of thinking in a person. New requirements arise for the teacher, he becomes a 
tutor providing assistance in setting ambitious goals, personal development, as well as educational and practical assistance at all stages of the implementation of a lean project.

M. Rother introduces the concept of kata coaching - this is a methodology for the coach to form a leader's thinking within the framework of the kata improvement structure for improving process. The purpose of this procedure is the development of a leader and this is done by defining the leader's knowledge of the leader as a coach and helping to expand this boundary [4].

What principles of training in lean manufacturing are of particular value and significance? The proposed principles of training in lean manufacturing are formulated on the basis of andragogical training principles of Zmeev S.I. [3, p.24-26] and finalized taking into account the specifics of training in lean manufacturing:

1. Systematic training. This principle includes compliance with the goals, content, forms, methods, means of training and evaluation of learning outcomes. For example, if we declare that the purpose of training is to obtain competencies in the field of lean technologies, then implementations of the principle of systematic training are given in table 2.

Table 2. Implementation of the principle of systematic training in teaching lean technologies

\begin{tabular}{|c|c|}
\hline Name & Examples in lean technology teaching \\
\hline Goals & Gaining lean technology competencies \\
\hline Content & $\begin{array}{c}\text { Depending on the subject of continuing education courses } \\
\text { (necessarily includes the principles and methods of lean } \\
\text { manufacturing, an interactive format, work on the site) }\end{array}$ \\
\hline Methods & Process factory, design work, other interactive training formats \\
\hline Result & $\begin{array}{c}\text { Implemented project in the field of lean technologies indicating } \\
\text { the results of the project }\end{array}$ \\
\hline Result evaluation & $\begin{array}{c}\text { Comparison of project results with reference results for already } \\
\text { implemented projects }\end{array}$ \\
\hline
\end{tabular}

2. The context of training (term of A. A. Verbitskiy). In accordance with this principle, training pursues vital goals for the student, and is also focused on fulfilling social roles, is built taking into account the student's professional activities. To do this, when teaching lean technologies, we organize excursions for our students, within which they could see the experience of applying the principles and methods of lean manufacturing.

3. The principle of urgency in applying the gained knowledge in practice. Lean knowledge is not given in reserve, but for a specific project. This principle is implemented through on-site training directly in the Gemba, which is the predominant form of training in the field of lean manufacturing. This restores the connection between words and deeds. All projects and ideas should be reflected in reality.

4. The principle of focused knowledge. Knowledge is given as a student develops needs for specific methods and tools of lean manufacturing. Knowledge for the task, directly to achieve a specific goal.

5. The principle of environmental friendliness of results and compliance with the values of lean manufacturing. It is about observance of such values as "respect for the person", "orientation on creating value for the client", "time", not only when implementing lean projects, but also in the educational process itself.

The implementation of these principles leads to a shift in emphasis in the educational process: from the theater of one actor, where the teacher played the leading role, we move on to directing the educational process, where:

the learning process is organized on the principle of "pulling", 
students work on improvements in working groups of 3-7 people, regularly present the results of their work,

there is a balance of trainer and group activity with a predominance of group activity

freedom in the meaningful activity of students, including in discussions, suggestions and the provision of group work results.

Let us dwell on the principle of pulling. Pulling is a process organization in which the supplier produces exactly as much as the consumer requires, and only when necessary. The basis of the pull is the rapid exchange of information and long-term partnerships between consumers and suppliers [1]. This principle is remarkably applied when teaching lean knowledge in the andragogical learning model.

The implementation of these principles of training in lean manufacturing involves the application of various forms of training, presented in Figure 2.

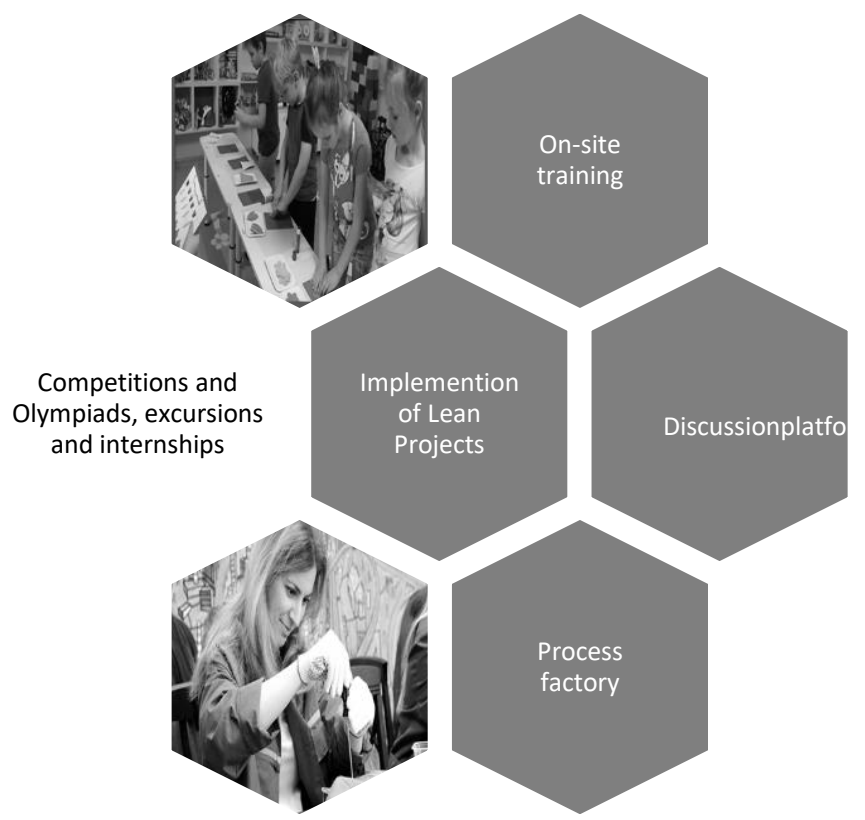

Fig. 2. Forms of training in lean manufacturing, compiled by the author

Process factory is a training platform for practical training in the principles and tools of lean manufacturing, where each participant gets acquainted with a real production process and gets practical experience in using lean manufacturing tools: mapping the process of creating value, organizing a workplace, Spaghetti chart, and many others. As a result of lean manufacturing methods application, the process is improved by 5-10 times, the skill of applying lean manufacturing methods is reinforced.

Since the process factory is a training that takes place in an interactive format, it is advisable to carry it out on a Kolb cycle. This is one of the learning models based on the phased formation of mental actions. The main four stages of the Kolb model are as follows:

1) Direct, specific experience - any person should already have some experience in the field he wants to learn.

2) Observation and reflection - this stage involves the deliberation and analysis of a person's experience and knowledge. 
3) Formation of abstract concepts and models - at this stage person builds a certain model that describes the information received, experience. Person generates ideas, builds relationships, and adds new information regarding how everything works and works.

4) Active experimentation - involves experimentation and testing the applicability of the created model, concept. The result of this step is an immediate new experience. Further, the circle closes [4].

\section{Results}

The use of the Kolb cycle at training courses on lean manufacturing will allow us to move on to the andragogical model of education, where the learner himself plays the leading role in organizing the learning process at all stages, where he conducts experiments and tests the applicability of the created model and concept. Thus, we will be able to learn not only to give new knowledge and competencies in the field of lean technologies, but also to form a lean personality.

\section{Conclusion}

The main pattern of lean transformations is that all changes begin with yourself. Everything external is a reflection of the internal state. Is a person ready to start a change for the better with himself? The answer to this question should not be limited to words. Of much greater importance are new thoughts and new actions. From changing habits to a new way of thinking and living. Let us refer to the opinion of the rector of the Maikop University Saida Kuizheva. In an interview with "Expert Yug" (August 2019), she said that a training center "Process Factory" was organized at Maikop State Technological University, where representatives of all levels of the educational system of the republic, state and municipal government, and social organizations began to take classes. According to Kuizheva, the university's path is "typical for universities in those regions in which, at the initiative and with the support of Rosatom, lean manufacturing philosophy, principles and tools were introduced in such large-scale projects as "Lean Government" and "Lean Polyclinic" [7].

\section{References}

1. GOST 56020 - 2014. Lean manufacturing. Fundamentals and vocabulary. Access mode: https://standartgost.ru/ (accessed October 21, 2019)

2. When studying the research topic presented, it is important to remember foreign authors, among them Malcolm Shepherd Knowles and his works: 1962 - A History of the Adult Education Movement in the USA, New York: Krieger. A revised edition was published in 1977; 1975 - Self-Directed Learning. Chicago: Follet; Knowles, M. (1984). The Adult Learner: A Neglected Species (3rd Ed.). Houston, TX: Gulf Publishing; 1984 - Andragogy in Action. San Francisco: Jossey-Bass; We also point out foreign works, including Joseph and Judith Davenport, "Andragogy: Another Bandwagon or Legitimate Tool in the Continuing Education Armamentarium?," ERIC Document ED263339 (October 1984); Joseph and Judith Davenport, "Knowles or Lindeman: Would the Real Father of American Andragogy Please Stand Up," Lifelong Learning. 9: 3, pgs 4-5 (Novem Grace AP Striking a Critical Pose: Andragogy - Missing Links, Missing Values. International Journal of Lifelong Education, 1996, vol. 5, no. 15, pp. 382-392; Merriam, SB (2001). Andragogy and self-directed learning: Pillars of adult learning theory. Merriam, SB (Ed.), The new update on adult learning theory: New directions for adult and continuing education. (Pp. 1-13); Blondy, LC (2007). Evaluation and 
application of andragogical assumptions to the adult online learning environment. Journal of Interactive Online Learning, 6 (2), 116-130; Henschke JA A Perspective on the History and Philosophy of Andragogy: an International Sketch. Proceedings of the Commission on International Adult Education Pre-Conference of the American Association for Adult and Continuing Education Conference. Cleveland, 2009, pp. 54129; Palis, AG \& Quiros, PA (2014). Adult learning principles and presentation pearls. Middle East African Journal of Opthamology, 21 (2), pp. 1 14-122.

3. Zmeev S.I. Adult Education Technology: Textbook. Manual for students of higher education institutions (Moscow, Publishing Center "Academy", 2002).

4. Toyota Kata: Leadership, management and employee development to achieve outstanding results. / M. Rother. 2014.

5. Pedagogical andragogy. Toolkit. Book 1. Modern adaptive systems and technologies of adult education / Ed. V.I. Podobed. (Saint-Petersburg, GNU "IAO RAO", 2003).

6. Kolb cycle. Access mode: http://trenerskaya.ru/article/view/cikl-kolba (accessed October 21, 2019)

7. Ksenia Kalinichenko, The first lean university // Expert Yug No. 8 (434) (2019). 